\title{
An Analysis of Hydro-energy Deficit in Nepal
}

\author{
Krishna Prasad Ojha \\ Lecturer, Nepal Commerce Campus, TU.
}

\begin{abstract}
Even though Nepal has a huge hydropower capacity, it has not been able to fully exploit this vast resource for economic growth. Despite having access to electricity, the country's power sector is underperforming, with supply shortages, reliability issues, and restricted access. Nepal has been able to produce about three percent of the economic viability and less than two percent of the total potentiality. If the investment priority is made in energy sector, it contributes sufficiently to the national economy. Still there is energy deficit in Nepal basically in dry season due to lower production and high demand.
\end{abstract}

Keywords: Hydropower, economic. Demand, supply, potential etc.

\section{Introduction}

Nepal Claims as second richest country for potentiality of hydropower in the world after Brazil. Dr. Hari Man Shrestha claimed through his $\mathrm{PhD}$ dissertation as the 83,000 MW potential. However, another more scientific study lead by Prof. Narendra Man Shakya has shown that Nepal has a total potential to generate 53,000 megawatts of hydropower. Another analysis showed an economically and technically feasible hydroelectric power of 43,000 MW (NPC, 1985). The general opinion, amid these differences, is that hydropower has the ability to uplift the Nepalese people's lives. Although it is not so long to discuss the history of electricity production in Nepal, 100 years have passed since the beginning of the construction of the Pharping Hydroelectric Plant (500 KW) in 1911, called Chandrajyoti Hydroelectric Power Station, the first hydroelectric power plant in South Asia. The country has since built numerous hydropower plants to meet the nation's never-ending demands (Shrestha, 1966).

One fifth of the world's electricity supply comes from hydropower, and hydropower production has encouraged and helped shape economic growth in many nations, such as Bhutan, Canada, Norway, and the United States (World Bank 2009). In addressing the rising worldwide demand for renewable, secure and affordable electricity, hydropower will play an important role. Moreover, well-designed and implemented multipurpose water infrastructure projects often provide other opportunities for growth, such as irrigation, fisheries and the supply of domestic and industrial water to developing countries (World Bank 2009; Billington and Jackson 2006; ICOLD 2010). Hydropower reduces the use of energy sources that are carbon intensive, such as coal, oil and gas, and also leads to the integration of other intermittent sources of renewable energy, such as solar and wind.

\section{Objective and Methods}

This analysis aims presenting and analyzing the hydropower potential and deficit between production and demand situation in Nepal. This analysis is made on the basis of literature survey and secondary data available from NEA and GON authorized economic surey. 


\section{Literature Review}

In economic development, the energy sector plays a very important role and evidence indicates that the expansion of the electricity sector in many countries leads to economic growth. A major growth constraint was the underperforming electricity sector in Nepal, which had an insufficient and unreliable supply of poor-quality electricity. This situation has improved, but even today, basic energy needs are still needed. Traditional sources also dominate the energy market, where fuel timber accounts for more than three-quarters of overall energy consumption. There are no recognized oil or gas resources in Nepal and all fossil fuels are imported. Around $89 \%$ of the population has access to electricity as of 2019 , but the supply is of low quality and unreliable. Despite the drastic rise in per capita electricity consumption, it remains among the lowest in the world, from 63 kilowatt-hours $(\mathrm{kWh})$ per year in 2000 to $177 \mathrm{kWh}$ per year in 2018; the per capita electricity consumption of Nepal is 20th of the global average.

During the 2000s, Nepal's economic growth was less than 4 percent per year. This slow growth is partly due to energy supply shortages for both conventional and new industries. This situation has changed, as it reported growth of about 6 percent in 2013 and about 7.3 percent on average from 2016 to 2018 , following a substantial slowdown mainly due to the impacts in 2014 and 2015. In particular, in the past 2 decades, the contribution of both the agricultural and industrial sectors to the gross domestic product (GDP) has decreased. While the relative contribution from the agricultural and industrial sectors has decreased, the services sector has increased, accounting for the largest share of Nepal's economy at present. In 2017, 51.6 percent of GDP was accounted for by utilities, followed by agriculture (26.2 percent) and manufacturing (13.4 percent ). The recent developments in the supply of electricity to the manufacturing and service sectors are thought to have led to stronger economic development. Along with rapid urbanization and a rising number of energy-intensive industries, this trend in the growth of the electricity sector is expected to continue. It is anticipated that unconstrained electricity demand will rise from an estimated 10,138 gigawatthours (GWh) in 2019-2020 to 31,196 GWh in 2029-2030 (Nepal 2019).

Against a peak electricity demand of 1,320 MW in fiscal year 2018-2019, the total installed generation capacity in Nepal is only 1,182 megawatts (MW). Of this, $621 \mathrm{MW}$ was owned by the Nepal Electricity Authority (NEA) (generating 34\% of the total electricity sold), while private investors owned $560 \mathrm{MW}$ of the total installed capacity (generating 29 percent of total sold electricity). By importing from India, the $g$ requirements were met by ( 38 percent of total electricity sale, maximum import of about $596 \mathrm{MW}$ ). Recent progress in hydropower production has already resulted in survey licenses for 302 projects with a total capacity of 15,885 MW, of which 172 have received generation licenses, and construction for a total capacity of 4,642 MW is ongoing. Power purchase agreements for 244 projects with a combined capacity of 4.138 MW have been completed.

NEA is a state-owned, vertically integrated utility responsible for the production, transmission, and distribution of electricity. It has the right to buy monopsony of the generation made by others. As a single off-taker, the NEA's poor financial health has therefore placed major fiscal burdens on the government and restricted the sector's ability to mobilize appropriate investment. Due to low creditworthiness and the absence of a mature regulatory climate, higher levels of private investment in large-scale hydropower projects have become a major constraint. Significant progress has been made in NEA's efficiency in recent years; however, unless key sector problems and constraints are resolved, these accomplishments are not likely to yield intended benefits in the longer run. This problem is directly influenced by two major issues: I insufficient planning, policy and regulation and (ii) inadequate capability and weak governance, leading to underinvestment and difficulty maintaining the growth of the power sector (ADB 2018). The energy sector's challenge is to increase investment, which includes establishing an encouraging investment climate regulated by a transparent and independent regulatory process that provides all stakeholders with a level playing field. The expeditious operationalisation of the newly formed Electricity Regulatory Commission is crucial in this respect. In the past, electricity prices in Nepal have been kept too low and below the level of cost recovery in the absence of sufficiently autonomous regulatory regimes. However, due to steps taken 
in the recent past, including putting an end to load shedding, controlling operational costs, and introducing financial reform initiatives, NEA was able to produce an operating profit in 2018. Profitability has also led to the low average price of imported energy. Even NEA has reported surplus position of revenue.

Nepal is endowed with enormous hydropower potential as she is blessed by the bequest of almost 6,000 rivers with their tributaries through the mighty Himalayan Range to her north while the country has as much as $83,000 \mathrm{MW}$ theoretical potential (Shrestha, 1966) with 43,000 MW economically feasible hydropower (NPC, 2002) at hand, Nepal has long been lagged in its generation with respect to its growing domestic demand and more importantly the ever increasing demand for electricity in the neighboring countries.

The electricity demand in Nepal is growing by 100 to 130 MW annually (Ministry of Finance, Nepal, 2074). Currently, electricity demand is $1444 \mathrm{MW}$ at peak time but country has supply position of hardly 961 MW including the 400 MW power imported from India in dry season, making short supply of electricity to $483 \mathrm{MW}$ per day. Meanwhile, the country is in rush of power generation by permitting construction licenses to mega hydro electric projects including Upper Tamakoshi (456 MW), Chamellia (30 MW), Budhi Gandaki (1200 MW), Upper Karnali (900 MW) and Arun Third (900 MW) among others. The power plant installation cost in Nepal is estimated to be 1.5 to 2 million dollar per Mega Watt depending upon the nature of project and type of geographic sites. The country targets to produce $2000 \mathrm{MW}$ electricity per year to turn out the electricity generation goal of $10000 \mathrm{MW}$ in coming five years as per power development plan of Government of Nepal. For accomplishment of such over ambitious target, the country needs to invest at least 4 billion dollar per year (i.e. $15 \%$ of GDP) in power development projects which is almost impossible to finance from internal capital markets. The country needs to appeal and facilitate global power investors in Nepal to overcome such huge financing gaps in power industry.

This study adopted the descriptive and analytical research strategy. The main objective of this study is to examine the gap between demand and supply of hydropower in Nepal. For the data collection, Nepal Hydroelectricity Authority's information through periodic bulletins and other publications are used. Simple statistical tools and charts are used to analyze the scenarios of hydropower potential and realized generation of power. Similarly, the gap between demand and supply of power is analyzed with the help of available data.

In the early years of hydro power development of Nepal, financing of power projects came through grants aid by neighboring countries. For example, India's grants were utilized to construct Trishuli (18 MW), Devighat (14.1 MW), Gandak (15 MW) and Surajpura-Kosi (20MW), Chinese assistance for Sunkoshi (10MW) and former USSR for Panauti (2.4 MW). Since 1970, bilateral and multilateral funds were available for hydropower development. The major donor countries in the period were Japan, Norway, Germany and South Korea including Canada, Finland, Denmark, Sweden and USA. The lending agencies were the World Bank, Asian Development Bank (ADB), Japan Bank for Industrial Corporation (JBIC) former Overseas Economic Co-operative Fund (OECF), Saudi Fund for Development, Kuwait Fund and others. Following the adoption of policy of economic liberalization since 1990 AD, hydropower development took a new turn with the private sector entering the arena (MOWR, 2004).

After promulgation of Hydro Electric Act (1992), private investment called independent power producers (IPP) entered into the sectors along with key contributory Nepal Electricity Authority (NEA) which has constructed major hydro power stations including Kaligandaki-A (144MW), Marshyangdi (69MW), Kulekhani-1\&2 (92MW), Trishuli (24MW), Gandak (15MW), Modi Khola (14.8MW) among others. Publicly held Hydro power companies like Butwal Power Company BPC), Chilime Hydro Power Company (CHPC), Himal Power Limited (HPL) Arun Valley Hydro Power Company Limited (AVHPL), Bhotekoshi Power Company (BKPC) National Hydropower Company Limited ( NHCL), Sanima Hydro Power Limited (SHPL) etc emerged as independent power producers in Nepal and developed power projects like Khimti-I (60MW), Bhotekoshi (36MW), Chilime(20MW) Jhimruk (12MW) Indrawati (7.5MW), Aandhikhola (9.4MW), Piluwa Khola (3MW), Sunkoshi Small (2.5MW) among others. With the entrance 
of national and foreign private investors in hydro power sector of Nepal, it has considerably changed the dynamics of hydro industry along with Nepalese capital market in which trading of stocks of hydro power companies constitute a major share of total market capitalization.

As is evident, no other source of energy other than hydropower can deliver multi-pronged benefits. Exploiting of hydro-resource ensures energy, food, and health security, preserves environment, reduces greenhouse gas emission, creates recreational facilities, and provides significant contribution to the poverty reduction and employment generation. Hydropower, therefore, is considered the backbone of Nepal's socioeconomic development.

While dealing with the specialization of Nepalese economy in terms of comparative advantage framework, the development of hydropower can play dominant role in leading a sustainable economy growth, both by providing cost efficient and environment friendly power supply to improve energy services to the nation and the neighboring countries. Considering this fact, the government of Nepal formulated Hydropower Development Policy, 2001 and Water Resources Strategy, 2002 with special emphasis on the promotion of private sector involvement in all large, medium and small scale hydropower development projects. In addition, the Government of Nepal has been developing hydropower projects through its own projects and through Nepal Electricity Authority using its own resources and with the support from donor institutions.

The Nepal government's white paper on the energy, water resources and irrigation sector aims to increase production capacity to $15,000 \mathrm{MW}$. The current peak load electricity demand of Nepal is around 1,500 MW (NEA, 2017). This is expected to increase to 2,379 MW by 2022 and 4,280 MW by 2030 in a business-as-usual scenario. But if there is reliable electricity for 24 hours per day then peak load demand for electricity would reach 2,744 MW by 2022 and 5,371 MW by 2030.In addition, around $95 \%$ of households in Nepal have access to electricity, out of which around $60 \%$ of households are connected to the grid, $10 \%$ by community rural electrification schemes, $18 \%$ by off-grid electrification schemes and $7 \%$ by stand-alone solar systems. Nepal is importing around $300 \mathrm{MW}$ of electricity from India, so the households' consumers are not facing power cuts. However, industries are still facing power cuts. Currently constructing hydropower projects are expected to add 3,000 MW by 2020 and soon Nepal will enjoy energy surplus (NEA, 2019).

But, despite a high potential of hydropower and its formidable scope in comparative advantage, Nepal has long been bearing shortage of electricity. This is primarily due to the lack of investment for the generation of hydroelectricity in different potential projects, while the seasonal shortage is due to severe variation of flow in Nepalese rivers between summer and winter seasons along with Nepal's weak planning to harness the hydropower potential.

While selecting the projects, Nepal has options of reservoir and run of river which could be selected on the basis of domestic demand, time of construction and operation, cost and economic benefits as well as environmental perspective.

The energy sector plays a very important role in economic development and evidence shows that the expansion of the electricity sector is contributing to economic growth in many countries. The underperforming electricity sector in Nepal, with inadequate and unreliable supply of low-quality electricity, was a major development constraint. This situation has improved, but even today the basic energy needs of Nepalese citizens are only partially met. The energy sector is still dominated by traditional sources, with fuel wood accounting for more than three quarters of total energy consumption. Nepal has no known oil or gas resources and all fossil fuels are imported. By 2019, about $89 \%$ of the population had access to electricity, but the supply was poor in quality and unreliable. Despite the dramatic increase in per capita electricity consumption, from 63 kilowatt-hours $(\mathrm{kWh})$ per year in 2000 to $177 \mathrm{kWh}$ per year in 2018, it remains one of the largest electricity consumption countries in the world; Nepal's electricity consumption per capita is one-twentieth of the global average.

Nepal's economic growth in the 2000 s was less than $4 \%$ per year. This slow growth is partly due to shortages in the supply of electricity for both traditional and modern industries. This situation has changed, 
with about $6 \%$ growth in 2013 and about $7.3 \%$ growth on average between 2016 and 2018 , following a significant slowdown in 2014 and 2015, mainly due to the impact of the earthquake. Specifically, the contribution of both the agricultural and industrial sectors to the gross domestic product (GDP) has decreased over the last two decades. While the relative contribution from the agricultural and industrial sectors decreased, the services sector has grown and currently accounts for the largest share of Nepal's economy. Services accounted for 51.6 per cent of GDP in 2017, followed by agriculture (26.2 per cent) and industry (13.4 percent). It is believed that recent improvements in the supply of electricity to the industrial and service sectors have contributed to better economic growth. This growth trend in the electricity sector is expected to continue along with rapid urbanization and an increasing number of energy-intensive industries. Unrestricted demand for electricity is expected to increase from an estimated 10,138 gigawatt-hours (GWh) in 2019-2020 to 31,196 GWh in 2029-2030 (Nepal 2019).

The total installed generation capacity in Nepal is only 1,182 megawatts (MW) compared to the peak electricity demand of 1,320 MW in the 2018-2019 fiscal year. Of these, the Nepal Electricity Authority (NEA) owned $621 \mathrm{MW}$ (34\% of total electricity sold) while private investors owned $560 \mathrm{MW}$ of total installed capacity (generating 29 percent of total sold electricity). The remaining requirements have been met by the import of electricity from India (38 percent of total electricity sale, maximum import of about 596 MW). The electricity generation capacity in Nepal is increasing rapidly. As regards recent progress in the development of hydropower, survey licenses for 302 projects with a total capacity of $15,885 \mathrm{MW}$ have already been issued, out of which 172 projects have been licensed for generation and construction is ongoing with a total capacity of 4,642 MW. Power purchase agreements have been concluded for 244 projects with a total capacity of 4,138 MW.

NEA, the Nepal Energy Agency, is a vertically integrated, state-owned utility responsible for the generation, transmission and distribution of electricity. NEA is the sole generator of other parties, including the generation owned by the private sector. The poor financial health of the NEA as the only off-taker therefore placed significant fiscal burdens on the government and constrained the sector's capacity to mobilize sufficient investment. The vertically integrated structure of the NEA, along with its poor creditworthiness and lack of a mature regulatory environment, has become a major constraint on higher levels of private investment in large-scale hydropower projects. Significant progress has been made in NEA performance in recent years; however, these achievements are unlikely to reap the expected benefits in the longer term unless key sector challenges and constraints are addressed. Two key issues have a direct bearing on this problem: I inadequate planning, policy and regulation; and (ii) inadequate capacity and poor governance leading to under-investment and difficulty in sustaining the growth of the power sector; (ADB 2018). The challenge for the energy sector is to increase investment, which requires the creation of an enabling investment environment governed by a transparent and independent regulatory process that provides a level playing field for all stakeholders. In this regard, the speedy operation of the recently established Electricity Regulatory Commission is crucial. Electricity prices in Nepal have remained too low and below cost recovery levels in the past in the absence of a sufficiently independent regulatory regime. However, NEA was able to generate operating profit in 2018 due to actions taken in the recent past, including putting an end to burden-sharing, controlling operating expenses and implementing financial reform measures. The low average price of imported electricity has also contributed to profitability.

The total number of consumers has increased by $7.88 \%$ from 3.91 million to 4.22 million during $2019 / 20$ in Nepal. Domestic consumer category remained the largest category with $93.26 \%$ share of the entire electricity consumers. (NEA, 2019/20) showed electricity supply-demand gap in the country is still significant. The electricity supply scenario is expected to improve significantly once the Upper Tamakoshi and other NEA/Chilime subsidiary projects are brought into operation shortly. Various generation projects from IPPs are also under construction and are expected to complete soon. NEA, thus is, also trying to diversify the use of electricity in other areas as electric vehicles (EV), cooking, heating and cooling, etc. 


\section{Discussion and Results}

Nepal has some 6,000 rivers with a total length of 45,000 kilometers $(\mathrm{km})$. The average water runoff from these rivers is approximately 220 billion cubic meters per year. Based on the availability of water resources, Nepal's technical potential for hydropower has been estimated to be 83 gigawatts (GW). Usually, due to other constraints, not all technically potential water resources will be developed. As a result, approximately $42 \mathrm{GW}$ is considered economically viable. The main river basins are Sapta Koshi, Karnali, Sapta Gandaki, Mahakali, and the Southern Rivers (Gurung and Oh, 2011); their respective generation capacity is presented in

Table 1

Hydropower potential in Nepal

\begin{tabular}{lcccc}
\hline Rivers & Theoretical Potential & Project Sites & Technical Potential & Economic Potential \\
\hline Saptakoshi & $22,350 \mathrm{MW}$ & 53 & $11,400 \mathrm{MW}$ & $10,860 \mathrm{MW}$ \\
Saptaandaki & $20,650 \mathrm{MW}$ & 18 & $6660 \mathrm{MW}$ & $5270 \mathrm{MW}$ \\
Karnali and Mahakali & $36,180 \mathrm{MW}$ & 34 & $26570 \mathrm{MW}$ & $25,125 \mathrm{MW}$ \\
Southern Rivers & $4,110 \mathrm{MW}$ & 9 & $980 \mathrm{MW}$ & $878 \mathrm{MW}$ \\
Total & $83,000 \mathrm{MW}$ & 114 & $45,610 \mathrm{MW}$ & $42,133 \mathrm{MW}$ \\
\hline
\end{tabular}

Source: ADB South Asia Working Paper Series No. 70 -2020: Hydropower Development And Economic Growth in Nepal.

Table 2

The current and predicted electricity demand and supply (in MW) in wet (April-November) and dry (November-April) seasons.

\begin{tabular}{lcccc}
\hline & FY & Demand & Supply & Balance \\
\hline \multirow{4}{*}{ Wet seasons } & $2018 / 19$ & 1841.13 & 2283.45 & 441.32 \\
& $2019 / 20$ & 2225.65 & 2856.97 & 631.32 \\
& $2020 / 21$ & 2638.29 & 3584.44 & 946.15 \\
& $2021 / 22$ & 3062.87 & 3963.87 & 901 \\
& $2022 / 23$ & 3365.97 & 4046.14 & 670.17 \\
Dry seasons & $2018 / 19$ & 1841.13 & 1470 & -372 \\
& $2019 / 20$ & 2225.65 & 1686 & -539 \\
& $2020 / 21$ & 2638.29 & 1928 & -709 \\
& $2021 / 22$ & 3062.87 & 2055 & -1007 \\
\hline
\end{tabular}

Source: Government of Nepal, Ministry of Finance. (2017). Economic Survey: Fiscal Year 2016/17. Kathmandu.

Table 3

The current and predicted future energy use in Nepal

\begin{tabular}{lcccccc}
\hline Index & 2005 & 2010 & 2015 & 2020 & 2025 & 2030 \\
\hline Per capita energy (GJ) & 15 & 16 & 16 & 17 & 19 & 23 \\
Per capita electricity (kWh) & 67 & 80 & 124 & 231 & 496 & 1070 \\
Household electricity use (\%) & 1 & 2 & 4 & 7 & 13 & 17 \\
Energy per household (GJ) & 76 & 79 & 78 & 78 & 13 & 17 \\
Non-carbon elect. share (\%) & 1.7 & 1.9 & 2.8 & 4.8 & 9.3 & 16.5 \\
Share of renewable (\%) & 11.7 & 11.9 & 11.2 & 12.3 & 15.4 & 22.1 \\
Imported electricity (\%) & 10.6 & 13.4 & 18 & 23.4 & 29.9 & 34.8 \\
Per capita GHG production (kg) & 474 & 459 & 420 & 392 & 508 & 672 \\
\hline
\end{tabular}

Source: GON, Guidelines for power system optimization of hydropower projects- (2015), p. 328 
According to these estimates, the Nepalese government anticipates a major rise in the country's energy consumption over the next decade. Simultaneously, the usage of renewable energy is expected to grow from $12 \%$ today to over $20 \%$ in the next ten years, while the country's reliance on imported electricity is expected to rise to $34 \%$, putting the country's economic independence at risk. Some experts argue that Nepal's reliance on foreign energy suppliers does not have a major effect on the country's energy security as long as the foreign suppliers are trustworthy. However, according to the energy consumption data in table 2 and the energy forecasts in table 3, Nepal's energy vulnerability is likely to worsen. The international oil markets' instability exacerbates the situation, making the energy crisis more serious and long-lasting.

Nepal is strategically situated between the two largest countries in Asia: India and the People's Republic of China (PRC). These two countries face an annual electricity demand of around 5 million GWh. Bangladesh is facing increasing energy demand and is also energy-efficient. Demand is also growing rapidly within Nepal. In addition to domestic and industrial use, Nepal also has a good potential to use electricity for transport. So far, Nepal has developed less than 1.2 GW of hydropower. Even with ongoing developments in hydropower, about 88 per cent of the economic potential of hydropower is available for further development. India, the PRC and other neighboring Asian countries such as Bangladesh could easily absorb any additional supply of electricity over and above the needs of Nepal, provided that appropriate transmission infrastructure is in place.

\section{Conclusion}

Even Nepal has a great potential of hydropower generation it has not been able to make full use of this vast resource for its economic development. Although sitting on electricity, the country has an underperforming power sector with supply shortages, reliability problems, and limited access to it. For any nation to modernize its economy and maintain economic development, it must have a sufficient supply of energy of reasonable quality. The only way out of Nepal's electricity sector's low investment balance is for public, domestic, private, and international agencies to invest in hydropower production. Although the situation has improved since 2016, further concerted public-sector efforts are needed to resolve the barriers to hydroponic production. The study looks at the ramifications of Nepal only realizing $20 \%$ of its economically viable hydropower capacity. The findings indicate that the electricity market, which has historically been a growth inhibitor, could become a major growth driver by 2030, increasing real gross domestic product (GDP) by $87 \%$ above baseline levels. Furthermore, the findings show that growing hydropower capacity will protect against the negative effects of oil price shocks on economic growth. Although higher oil prices are dampening the positive growth effects, rapid hydropower expansion is providing major economic growth benefits.

\section{References}

ADB, (2020). Hydropower Development and Economic Growth In Nepal: South Asia Working Paper Series No. 70. , Mandaluyong City, 1550 Metro Manila, Philippines.

Agrawala, S. et al. (2003). Development and Climate Change in Nepal: Focus on Water Resources and Hydropower. Paris: OECD.

Ansar, A. et al. (2014). Should we build more large dams? The actual costs of hydropower megaproject development. Energy Policy, 69: pp. 43-56.

Government of Nepal, Ministry of Finance. (2011). Economic Survey: Fiscal Year 2010/11. Kathmandu. Government of Nepal, Ministry of Finance. (2012). Economic Survey: Fiscal Year 2011/12. Kathmandu.

Gunatilake, H., Wijayatunga, P., \& Roland-Holst, D. (2020). Hydropower development and economic growth in Nepal.

Government of Nepal, Ministry of Finance. (2015). Economic Survey: Fiscal Year 2014/15. Kathmandu. Government of Nepal, Ministry of Finance. (2017). Economic Survey: Fiscal Year 2016/17. Kathmandu. Gurung, A. et al. (2012). The Prospects of Renewable Energy Technologies for Rural Electrification: A 
Review from Nepal. Energy Policy. Volume 40 (C). pp. 374-380.

Gurung, A., \& Oh S. (2013). Conversion of Traditional Biomass into Modern Bioenergy Systems: A Review in Context to Improve the Energy Situation in Nepal. Renewable Energy. Volume 50 (C). pp. 206-213.

NEA. 2011. A Year in Review: Fiscal Year 2010/11. Kathmandu.

NEA. 2012. A Year in Review: Fiscal Year 2011/12. Kathmandu.

NEA. 2019/20. A Year in Review: Fiscal Year 2019/20. Kathmandu.

Nepal Electricity Authority (NEA). (2010). Annual Report of Nepal Electricity Authority: Fiscal Year 2009/2010. Kathmandu.

Shrestha, H. M. (1966).Cadastre of hydropower resources (Doctoral thesis). Moscow Power Institute, Moscow, USSR.

Surendra, K. et al. (2011). Current Status of Renewable Energy in Nepal: Opportunities and Challenges. Renewable and Sustainable Energy Reviews. Volume 15. pp. 4107-4117.

World Bank. (2009). Directions in Hydropower. Washington, DC. http://documents.worldbank.org/curated/ en/164581468336679451/Directions-in-hydropower

World Commission on Dams. 2000. Dams and Development: A New Framework for Decision-Making. UK: Thanet Press. 